Premio de artículos jurídicos «GARCÍA GOYENA» (Curso 2013-2014)

Premio: segundo accésit

\title{
SITUACIÓN ACTUAL DE LA GESTACIÓN POR SUSTITUCIÓN
}

\section{CURRENT STATE OF SURROGATE MOTHERHOOD}

\author{
SiLVIA VILAR GonZÁLEZ
}

Síntesis: La gestación por sustitución es una de las últimas opciones a la que acuden aquellas personas que quieren formar una familia y que no disponen de otros medios para ello.

En España, es una práctica prohibida y sancionada con la nulidad de pleno derecho. No obstante, la viabilidad para lograr la inscripción de la filiación del nacido, hace que muchos sigan optando por ella.

El presente trabajo realiza un estudio de la situación legal existente tanto en nuestro país como en el resto del mundo, con mención a los múltiples problemas que los interesados pueden encontrar a lo largo de este complicado proceso.

Abstract: Surrogate motherhood is one of the latest options requested by couples willing to raise a family with no other means to do so.

Surrogacy is illegal in Spain and regarded as null and void. Nevertheless, the viability to achieve the registration of the child's parentage makes many people opt for it.

This paper analyses the current state of affairs in our country as well as in the rest of the world, including the multiple implications involved in such a complex process. 
Palabras clave: gestación por sustitución / interés superior del menor / inscripción registral / incumplimiento

Key words: surrogacy / the best interests of the child / registration / breach of contract

Sumario: I. Introducción. II. Concepto, tipos y orígenes. III. Situación legal de la paternidad subrogada en el mundo. IV. La regulación española. V. La inscripción del menor en el Registro Civil Español. VI. Procedimientos de inscripción en base a la vigente Ley sobre el Registro Civil de 1957. VII. El nuevo procedimiento de inscripción de documentos judiciales previsto en la Ley 20/2011 del Registro Civil. VIII. Problemas que el incumplimiento del contrato puede plantear en la práctica. IX. Conclusiones. X. Bibliografía.

\section{INTRODUCCIÓN}

En base a estudios epidemiológicos efectuados en países occidentales, la esterilidad afecta al quince por cien de la población en edad reproductiva, es decir, a una de cada seis parejas, experimentando una evolución creciente ${ }^{1}$. Ello se debe, entre otros motivos, a que cada vez se decide acceder a la paternidad a una edad más avanzada, lo que influye directamente en la capacidad reproductiva tanto de hombres como mujeres, puesto que el retraso en la maternidad hace que aumenten las dificultades para concebir ${ }^{2}$.

Dichas personas, ante su imposibilidad natural de gestar, y tras seguir todo tipo de costosos y, en ocasiones, ineficaces tratamientos para tratar de tener un hijo, consideran como una de las últimas opciones para alcanzar su sueño, el acceso a la gestación por sustitución, también conocida como vientres de alquiler, maternidad por subrogación, paternidad subrogada, madres o úteros de alquiler, etc., la cual consiste en el encargo realizado por una persona o una pareja a una mujer que, gratuitamente o a cambio de contraprestación económica, se compromete a gestar en su vientre al futuro hijo de aquéllos, que les

\footnotetext{
${ }^{1} \mathrm{http}: / /$ www.europa-press.es/salud/salud-bienestar/noticia-infertilidad-afecta15-parejas-edad-reproductiva-representa-en-fermedad-20120516135107.html, etc. Última consulta: 01/03/2013.

${ }^{2}$ Soto LAMADRID, M. A. menciona que influyen decisivamente en la esterilidad humana, además del acceso tardío al matrimonio, aspectos como el abuso del alcohol, el tabaco y las drogas, el estrés de la vida moderna, los antecedentes de abortos y enfermedades venéreas, o el uso de dispositivos intrauterinos (cit. en «Biogenética, filiación y delito». Editorial Astrea. Buenos Aires, 1990. Pág. 6.).
} 
será entregado una vez se produzca el alumbramiento, renunciando la gestante a todo derecho que pudiera ostentar sobre el menor.

En España, la Ley sobre Técnicas de Reproducción Humana Asistida $^{3}$ declara expresamente la nulidad del contrato de gestación por sustitución. No obstante, existen mecanismos que permiten directamente la inscripción de los nacidos a través de esta técnica si se cumplen determinados requisitos, por lo que la población española no duda en acudir a dicha figura en los países extranjeros en que está permitida, especialmente, ciertos Estados de EEUU, India o Rusia, quizás por el desconocimiento de las consecuencias jurídicas que dicha práctica les puede suponer.

Es innegable que el Derecho de familia y, más concretamente la filiación, progresa de la mano de los continuos avances médicos que ofrecen nuevas opciones en materia de reproducción asistida e investigación ${ }^{4}$, pero también innumerables problemáticas de orden ético, jurídico, psicológico, social, sociológico, económico, religioso, científico, etc. ${ }^{5}$, que precisan de una regulación que ofrezca soluciones y proteja los intereses de los posibles afectados, y especialmente a los niños, ya que, nos guste o no, en el caso de la gestación por sustitución, nos encontramos ante una realidad social que se encuentra en auge en los últimos años.

Estos procesos son cada vez más frecuentes, no sólo debido al aumento de la esterilidad, sino también a la legalización de las parejas del mismo sexo que desean acceder a la paternidad, así como al deseo de muchas personas de ser padres o madres de forma individual, sin formar una pareja.

Todos ellos son conscientes de su voluntad de ser padres, pero no lo son de las complicaciones legales, burocráticas y médicas que el proceso comporta, unido al especial estado emocional en que vivirán la situación de la futura paternidad por todos los obstáculos que irán encontrando, y al elevado coste económico que les va a suponer. De ahí que precisen de un asesoramiento integral que les guíe a lo largo de todo el camino, hasta la efectiva inscripción del nacimiento del menor y consiguiente reconocimiento de la filiación en España.

${ }^{3}$ Ley 14/2006, de 26 de mayo, sobre técnicas de reproducción humana asistida. BOE núm. 126, de 27 de mayo de 2006, páginas 19947 a 19956.

${ }^{4}$ García RuIZ, Y.: "Reproducción humana asistida. Derecho, conciencia y libertad». Ed. Comares. Albolote (Granada), 2004. Pág. 51.

${ }^{5}$ Vid. MÉndez Baiges, V. y Silveira Gorski, H. C.: «Bioética y derecho». Editorial UOC. Barcelona, 2007. Pág. 121 y ss. 
Por todos estos motivos hemos elegido este tema de investigación, puesto que, además de ser de máxima actualidad ${ }^{6}$, convive con el confuso panorama legislativo español actual. Creemos necesario dejar de lado opiniones personales o posibles dilemas éticos y abordar la realidad social para tratar de proteger, no sólo el interés superior del menor, sino también los derechos de la madre gestante y de los padres comitentes ante los innumerables incidentes, abusos y problemas que pueden surgir a lo largo de este proceso, principalmente los derivados del incumplimiento del contrato, como veremos ${ }^{7}$, para lo cual es de suma importancia disponer de un conocimiento exhaustivo y actualizado de la legislación del país donde se acudirá a formalizar el contrato de gestación por sustitución, las cuales se encuentran en constante proceso de cambio, así como el modo y viabilidad de lograr la inscripción del nacimiento del recién nacido en la Oficina consular española, para que la decisión de los futuros padres se adopte con verdadero conocimiento de causa.

\section{CONCEPTO, TIPOS Y ORÍGENES}

El concepto legal de la conocida en nuestra legislación como «gestación por sustitución», se halla en el artículo 10.1 de la Ley 14/2006, de 26 de mayo, sobre Técnicas de Reproducción Humana Asistida, que la define como «el contrato por el que se convenga la gestación con o sin precio, a cargo de una mujer que renuncia a la filiación materna a favor del contratante o de un tercero».

No obstante, una definición más amplia y comúnmente aceptada por la doctrina es la que resulta de la sentencia n. ${ }^{\circ} 826$ de la Sección $10{ }^{a}$ de la Audiencia Provincial de Valencia, de 23 de noviembre de 2011 que establece que la gestación por sustitución «consiste en un contrato, oneroso o gratuito, a través del cual una mujer consiente en llevar a cabo la gestación, mediante técnicas de reproducción asistida, aportando o no también su óvulo, con el compromiso de entregar el nacido a

${ }^{6}$ Han tenido hijos a través de madres subrogadas, entre otros, Sir Elton John, Sarah-Jessica Parker, Nicole Kidman, Sharon Stone, Michael Jackson, Dennis Quaid o Miguel Bose, siendo habitual en la prensa noticias relacionadas con los vientres de alquiler.

${ }^{7}$ Entre otros problemas, CARCABA FERnÁNDEZ, M. en «Los problemas jurídicos planteados por las nuevas técnicas de procreación humana», J. M. Bosch Editor, S. A., Barcelona, 1995, págs. 167 a 168, cita, entre otros, la posibilidad de que la gestante desee quedarse con el bebé nacido, que ni la madre subrogada ni los padres intencionales quieran quedarse con el niño, o incluso que la madre gestante muera como consecuencia del parto.

${ }^{8}$ Id. Cendoj: 46250370102011100707. 
los comitentes, que pueden ser una persona o una pareja, casada entre sí o no, que a su vez pueden aportar o no sus gametos».

En ambos casos, se habla de un contrato, en el que podrá mediar precio o realizarse gratuitamente, con dos partes intervinientes: por un lado, los futuros padres que efectúan el encargo -en adelante, padres comitentes-, que podrán ser una persona o una pareja, matrimonio o no, de carácter heterosexual u homosexual, y que pueden aportar sus propios gametos o no; y, por otro, la mujer -en adelante, madre subrogada, gestante, portadora, etc.- que se compromete a gestar en su vientre a un niño, al que entregará a los padres comitentes una vez producido el parto, con la consiguiente renuncia a todos los derechos que le pudieran corresponder sobre el niño, fundamentalmente, a la filiación que le pertenecería como madre.

Sería conveniente que el acuerdo se formalizara por escrito, con todos los requisitos y condiciones a que se somete la relación contractual, y si se suscribiese en documento público, el fedatario podría comprobar la capacidad de obrar de las partes y la prestación voluntaria del consentimiento, sin mediar coacción ni violencia, extremo fundamental a la hora de proteger a la madre gestante frente a posibles abusos. Los respectivos derechos y obligaciones de los firmantes dependerán de la legislación del país en el que se otorgue el convenio, ante cuya jurisdicción deberá acudirse en el caso de que su clausulado se incumpla por cualquiera de ellos.

Este contrato, que podría equipararse al de arrendamiento de obra o de servicios en el caso de hallarse tipificado ${ }^{9}$, es el que marca el inicio de la relación entre la madre subrogada, los padres comitentes y el equipo médico interviniente en el proceso.

En cuanto a las modalidades que puede revestir, existen varios tipos de clasificaciones:

a) Por un lado, podemos encontrarnos ante la variante "gestacional» o la «tradicional». En la primera de ellas, la madre subrogada tan sólo llevará adelante el embarazo en su vientre y no tendrá ninguna relación genética con el bebé nacido, pudiendo ser utilizados para la fecundación gametos de los futuros padres, o bien de donantes anónimos, que serán introducidos en la madre portadora a través de la técnica de la fecundación in vitro (FIV). En cambio, en la segunda opción, la mujer gestante aportará tanto su útero, como sus propios óvulos que serán

${ }^{9}$ Díaz Romero, M. R.: «La gestación por sustitución en nuestro ordenamiento jurídico», Diario La Ley, n. ${ }^{\circ}$ 7527, Madrid, 2010, pág.1. 
fecundados, habitualmente, mediante inseminación artificial (IA). Este último supuesto no se trata estrictamente de un vientre de alquiler, ya que la subrogada se convertirá también en la madre biológica del niño, lo cual no es muy recomendable al ser mayor la problemática que se podría suscitar al existir un vínculo biológico, y está expresamente prohibido en muchos ordenamientos en los que sí se permite la gestacional.

b) Por otro lado, la gestación por sustitución podrá realizarse de modo altruista, es decir, sin contraprestación alguna a cambio de la misma (aunque permitiendo ciertos ordenamientos jurídicos que se satisfagan los gastos estrictamente necesarios derivados de la gestación), o bien, bajo la modalidad conocida como "subrogación comercial», en la que la madre subrogada llevará a cabo el embarazo a cambio de un precio.

A partir de la irrupción de nuevas técnicas de reproducción asistida, el nacimiento del primer bebé probeta en julio de 1978, y, por tanto, de nuevos medios para formar una familia, se han quedado obsoletos los supuestos de filiación previstos en el artículo 108 del Código Civil (filiación por naturaleza -matrimonial o no matrimonialy filiación por adopción), mostrándose claramente el Derecho algo rezagado con respecto a la realidad social existente debido a los numerosos debates y dilemas éticos que surgen en torno a estos supuestos, especialmente, en relación con la técnica de la gestación por subrogación, que quiebra claramente los tradicionales principios jurídicos de Derecho romano «mater semper certa est» y «pater est quem nuptiae demostrant», ya que permite separar el hecho de tener hijos de la unión sexual entre el varón y la mujer, e incluso que se pueda procrear sin la participación biológico-genética de la pareja y/o sin su conocimiento ${ }^{10}$.

El primer contrato formal ${ }^{11}$ suscrito entre una madre subrogada y una pareja comitente se otorgó en 1976 en Michigan (EEUU), bajo la supervisión del abogado Noel Keane y con las variantes tradicional y altruista. Poco después, en el año 1980 tuvo lugar la subrogación comercial, por la cual una mujer de Illinois, conocida bajo el pseudónimo de Elizabeth Kane, aceptó convertirse en madre de alquiler a cambio de una contraprestación económica de diez mil dólares. Sin embargo, tras dar a luz se mostró reacia a entregar al bebé, por lo que

${ }^{10}$ MoRÁn DE VicenZI, C.: «El concepto de filiación en la fecundación artificial», Perú, 2005, pág. 161.

${ }^{11} \mathrm{http}: / / \mathrm{www}$. fertilityproregistry.com/article/the-history-of-surrogacy.html. Última consulta: $01 / 03 / 2013$. 
tuvo muchos problemas legales, hasta que al final le fue denegada la custodia del niño en base al convenio que había suscrito.

No obstante, los orígenes remotos documentados de dicha práctica, se remontan a varios miles de años atrás, cuando en Mesopotamia era frecuente que las mujeres estériles acudieran a la subrogación tradicional para no ser marginadas y apartadas de la sociedad por no ser capaces de engendrar, permitiéndoseles ofrecer una sierva a sus esposos y reconocer como propios a los hijos nacidos de dicha unión. Así, encontramos referencias expresas en el Antiguo Testamento de la Biblia, dónde Sara (Génesis 16 1-4), ante la imposibilidad de darle hijos a su esposo, el profeta Abraham, le dijo a éste: "Mira, Yahveh me ha hecho estéril. Llégate, pues, te ruego, a mi esclava. Quizá podré tener hijos de ella». O Raquel (Génesis 30 1-6) que, tras el nacimiento del hijo que su esposo Jacob concibió con su criada, manifestó: «Dios me ha hecho justicia, pues ha oído mi voz y me ha dado un hijo».

\section{SITUACIÓN LEGAL DE LA PATERNIDAD SUBROGADA EN EL MUNDO}

\section{a) Posturas mayoritarias}

Tres son las principales posturas adoptadas en relación con la paternidad subrogada.

En primer lugar, varios Estados de EEUU o países como Rusia, India, Ucrania, Georgia o Armenia, permiten acudir a esta técnica a título gratuito o a cambio de contraprestación económica.

En segundo lugar, países europeos como Reino Unido, Grecia, Holanda, Bélgica o Dinamarca, y otros como República Sudafricana, Brasil, Ecuador, Israel o Canadá, que la admiten pero sólo en caso de que se realice altruistamente y concurran ciertos requisitos o condiciones, principalmente relacionados con problemas médicos en la madre comitente que le impidan la gestación.

Y finalmente, nos encontramos con un tercer grupo de países que prohíben expresamente cualquier contrato de gestación por sustitución, tanto comercial como altruista. entre los que se encuentra España, la mayor parte de países europeos, como Austria, Italia, Alemania, Hungría, Islandia o Serbia, ciertos Estados de EEUU o Hong Kong, y también países como Arabia Saudí o Pakistán en que sus autoridades religiosas no lo autorizan, entre muchos otros. 
También es preciso citar supuestos excepcionales como el de China, en la que está proliferando dicha práctica a pesar de prohibirla expresamente el artículo 22 de su Ley de Regulación de Tecnologías sobre Reproducción Humana Asistida de 2001'2. O Tailandia, donde también se lleva a cabo sin estar expresamente permitida ni prohibida legalmente, lo que hace que no sea posible exigir el cumplimiento de un convenio en caso de que surgiera algún problema a lo largo del proceso, existiendo actualmente una propuesta de Ley para la protección de los niños nacidos a través de la subrogación, de las madres gestantes y para regular las relaciones legales entre los padres comitentes y las madres subrogadas ${ }^{13}$, que todavía no ha sido aprobada definitivamente.

En el plano internacional, los países están tendiendo a regular dicha realidad a la que cada vez más personas está recurriendo, con la finalidad de aportar soluciones y proteger no sólo el interés superior del niño, sino también la situación y derechos de la madre gestante y de los padres comitentes ante todas las cuestiones, abusos y problemas que pueden surgir a lo largo del proceso. Con la regulación, unos países tienden a flexibilizar las exigencias (como Rusia, que ya permite la subrogación a parejas no casadas o personas individuales), y otros, en cambio, fijan una regulación más restrictiva (como la India, en que tan sólo se permitirá en un futuro acceder a la paternidad subrogada a parejas heterosexuales con al menos dos años de matrimonio).

\section{b) Panorama legislativo de alguno de los países más representativos en la materia}

En Estados Unidos, la situación varía enormemente de un Estado a otro, hallándose expresamente permitida en algunos, prohibida en otros y con un panorama confuso en otros -no siendo clara ni la legislación, ni la jurisprudencia existente al respecto-. La normativa que será de aplicación, dependerá del Estado en que reside la madre subrogada, el lugar en que se suscribe el convenio y, finalmente, dónde tendrá lugar el alumbramiento.

\footnotetext{
12 Regulations on Human Assisted Reproductive Technologies promulgated by the Ministry of Health and enforced on August 1, 2001. http://www.chinaphs.org/ bioethics/regulations_\&_laws.htm. Última consulta: 19/02/2013.

${ }_{13} \mathrm{http}: / /$ www.thailawonline.com/en/family/children/surrogacy-laws-in-thailand. html. Última consulta: 21/02/2013.
} 
En cuanto a los Estados en que está permitida, su legislación también varía completamente de unos a otros, siendo los considerados más flexibles California, Arkansas, Illinois y Maryland.

Illinois dispone de legislación ${ }^{14}$ muy permisiva que regula desde la firma del convenio hasta la emisión de los Certificados de Nacimiento. No obstante, tan sólo se permite acceder a esta figura a personas, ya sean individuales o parejas heterosexuales, que hayan aportado sus propios gametos.

En California, encontramos la protección jurisprudencial más relevante a favor de los padres comitentes, a quienes declara legalmente los padres del niño nacido, tengan o no conexión genética con el mismo. Se admite la subrogación comercial, se obliga al cumplimiento de los convenios suscritos al efecto, y se permite a los padres comitentes, independientemente de su estado civil u orientación sexual, ser considerados padres legales antes del nacimiento y sin necesidad de acudir a procedimientos de adopción.

En Arkansas, el Acta 647 de 17 de marzo de 198915, prevé que el niño nacido como resultado de un tratamiento de inseminación artificial, sea reputado directamente como hijo biológico del padre y de su esposa -aunque ésta última no tenga conexión genética con el bebé-, o sólo del padre biológico -si no está casado-, o de la madre comitente -si el esperma para el proceso fue donado-. A la hora de registrar el nacimiento, la madre gestante se presume que es la madre natural, pero se puede obtener un certificado de nacimiento alternativo expedido por los Tribunales.

En cambio otros Estados, a pesar de admitir la gestación subrogada, establecen ciertas limitaciones o restricciones en torno a la misma. Como Dakota del Norte, en la que se permite la subrogación gestacional pero está prohibida la tradicional, o el Estado de Washington, en que se permite la subrogación altruista pero no la comercial. En Nevada se admite la subrogación gestacional, pero tan sólo entre parejas heterosexuales legalmente casadas.

También existen Estados, como Idaho, Oregón o Carolina del Sur, en que no existe ley que regule la subrogación, pero en los que la jurisprudencia ha sido habitualmente favorable a la misma, y otros como Maryland, Ohio o Pennsylvania, en que no existen leyes que

${ }^{14}$ Families (750 ILCS 47/) Gestational Surrogacy Act. http://www.ilga.gov/legislation/ilcs/ilcs3 . asp?ActID =2613\&ChapterID=59. Última consulta: 19/02/2013.

${ }^{15}$ Act 647 of the 1989 Regular Session. Approved: March 17, 1989. http://www. arkleg.state.ar.us/ assembly /1989/R/Acts/647.pdf. Última consulta: 18/02/2013. 
regulen dicha técnica, y en los que tampoco la jurisprudencia es uniforme al respecto.

Existe finalmente otro grupo de Estados que prohíben y castigan la subrogación comercial. Como Michigan, donde los acuerdos están legalmente prohibidos y se sancionan con fuertes multas económicas e incluso penas de prisión. O el Estado de Nueva York, en que se sancionan los contratos de subrogación comercial por contravenir el orden público, pero se admiten los contratos de subrogación altruista, aunque sin poderse exigir judicialmente su cumplimiento.

India ha sido también uno de los principales países a los que se ha recurrido para optar por la maternidad subrogada, tanto por su menor coste económico como por la flexibilidad, ya que al no existir ninguna ley que la prohibiese, se llevaba a cabo ampliamente, altruista y comercialmente. No obstante, existe desde el 2010 un borrador de propuesta de Ley de Regulación de Técnicas de Reproducción Asistida (ART), en trámites de aprobación en el Parlamento, que exigirá, entre otros, que el procedimiento de subrogación se lleve a cabo en clínicas reconocidas por el Consejo Indio para la Investigación Médica (ICMR) y que tan sólo permitirá el acceso a la subrogación a parejas heterosexuales que lleven al menos dos años casadas, y ya no a parejas homosexuales, parejas no casadas o personas solteras.

Como un primer paso a la regulación, en julio de 2012 fue dictada por su Ministro de Asuntos Interiores una Orden que ya no permite el uso del visado turístico a extranjeros que visiten India a efectos de acceder a la subrogación en dicho país, siendo preceptiva en lo sucesivo la obtención de un visado médico, con requisitos más duros ${ }^{16}$. Dicha orden exige a los comitentes que, mediante un certificado emitido por el Ministerio de Asuntos Exteriores de su país de origen o la Embajada correspondiente en India, acrediten que en dicho país de origen se admite la subrogación y que no tendrán problemas para que el o los bebés entren en el mismo, lo cual ha supuesto infinidad de problemas a diversas parejas españolas que se hallaban en trámites de traer a España a sus hijos y que no lograban acreditar los requisitos de la orden por estar la subrogación prohibida en nuestro país ${ }^{17}$.

En cuanto a Ucrania, sus leyes son completamente permisivas con la paternidad subrogada, incluyendo la posibilidad de seleccionar

${ }^{16} \mathrm{http} / / /$ www.bionews.org.uk/page_359997.asp. Última consulta: 13/12/2013.

${ }_{17} \mathrm{http} / / /$ sociedad.elpais.com/sociedad/2013/08/26/actualidad/1377541171_287106. html, http://www.elmundo.es/elmundo/2013 /08/29/espana/1377774180.html o http:// www.abc.es/sociedad/20130906/abci-bebes-vientre-alquiler-india-201309061942.html. Última consulta: 18/02/2013. 
el sexo del bebé. La ley no confiere a la gestante ningún derecho sobre el bebé, ni figurará su nombre en el Certificado de Nacimiento, estableciendo su Código de Familia ${ }^{18}$, que los comitentes serán legalmente los padres del niño gestado. No obstante, sólo podrán acceder a la subrogación gestacional, parejas heterosexuales casadas o personas individuales.

En Rusia, se establece el régimen jurídico en la materia en su Código de Familia (artículos 51 y 52), que defiende tanto los derechos de la madre gestante como los de los padres comitentes. La Ley federal No. 323-FZ sobre las Bases de Protección de la Salud de los Ciudadanos de la Federación rusa ${ }^{19}$, confiere a parejas o a mujeres solteras, independientemente de su estado civil, el derecho a participar en el programa de maternidad subrogada. Sin embargo, no se permite acceder a este programa a parejas del mismo sexo ni a hombres solteros, ya que la Orden No. $67^{20}$, exige la existencia de determinadas indicaciones médicas en la madre comitente para recurrir a un programa de gestación por sustitución (ausencia de útero, deformaciones del cérvix que carezca de tratamiento, enfermedades somáticas que contraindiquen la gestación, etc.). Finalmente, el artículo 16 de la Ley Federal No. 143-FZ sobre Actas de Estado Civil ${ }^{21}$, permite a los padres comitentes ser inscritos directamente en el Libro de Nacimientos como padres del niño, si la madre gestante presta su consentimiento para ello.

Entre los países que admitan tan sólo la subrogación altruista, destaca Reino Unido, cuya Acta de Acuerdos de Subrogación de $1985^{22}$ prohíbe expresamente la subrogación comercial. Su Acta de Fertilización y Embriología Humana ${ }^{23}$ permite, no obstante, que se

${ }^{18}$ Family Code of Ukraine. Vigor 1/1/2004. http://r-u.org.ua/en/analitika/pravo/149news.html. Última consulta: 19/02/2013.

${ }^{19}$ Federal Law No. 323-FZ of the Russian Federation «On Fundamentals of Health Protection of Citizens of the Russian Federation», from November 21, 2011. Vigor 1/1/ 2012. http://www.impowr.org/wip/russian-federation/Custody\% 20and\%20Adoption. Última consulta: 18/02/2013.

${ }^{20}$ Russian Federation Ministry for Health. Order Nr. 67, from February 26, 2003, «about Use of Assisted Reproduction Technologies (ART) for treatment of infertility in Female and Male Patients». http://www.omicsonline.org/scientific-reports/srep207. php. Última consulta: 18/02/2013.

${ }^{21}$ Federal Law No. 143-FZ of the Russian Federation «About acts of civil status», from November 15, 1997. http://cis-legislation.com/document.fwx?rgn=1770. Última consulta: 18/02/2013.

${ }_{22}$ Surrogacy Arrangements Act 1985. http://www.legislation.gov.uk/ukpga/1985/49. Última consulta: 20/02/2013.

${ }^{23}$ Human Fertilization and Embryology Act 2008. http://www.hfea.gov.uk/501. html\#mandatoryExtra. Última consulta: 03/02/2013. 
satisfagan los gastos razonables en que la madre de alquiler haya incurrido, no cualquier otra cantidad adicional. Se reconocen los acuerdos de subrogación, pero no se garantiza el cumplimiento de los mismos, ya que la gestante será la madre legal del niño hasta el momento en que los comitentes obtengan una orden judicial que establezca la filiación («paternal order») o una orden de adopción que les convierta en los padres legales del menor, permitiéndose a la gestante conservar los derechos legales sobre el niño aunque no tenga vinculación genética con el mismo.

En República Sudafricana, la paternidad subrogada se regula en los artículos 292 a 303 del Acta de los Niños 38 de $2005^{24}$, en vigor desde el abril de 2010, que admite tan sólo su modalidad altruista, pero permitiendo abonar a la madre subrogada los gastos derivados del trámite (médicos, legales, hospitalarios, de seguro, etc.), así como los ingresos que la gestante dejara de percibir como consecuencia de la gestación. Se requiere que los acuerdos de subrogación se realicen por escrito y que sean confirmados por los Tribunales. Un acuerdo válidamente celebrado tendrá como efecto que los nombres de los padres comitentes aparezcan directamente en el certificado de nacimiento del menor.

Los comitentes podrán ser una persona individual o una pareja, incluso del mismo sexo, pero se requiere que los gametos de, al menos uno de ellos, sean utilizados para la concepción. Se exige, asimismo, que el o los comitentes no sean capaces de dar a luz a un niño por motivos permanentes e irreversibles, y que la madre gestante tenga al menos un hijo propio. En caso de que la madre subrogada haya aportado su propio óvulo para la fertilización, tendrá derecho a romper el acuerdo de subrogación y reclamar el hijo para sí, sin incurrir en ninguna responsabilidad al respecto, debiendo tan sólo devolver a los padres comitentes los gastos que éstos le hayan abonado durante el embarazo.

En Canadá, el Acta de Reproducción Asistida Humana ${ }^{25}$, prohíbe expresamente pagar, tanto a la madre subrogada, como a los intermediarios, pero no prohíbe la subrogación altruista siempre y cuando la gestante sea mayor de 21 años. No obstante, el Código Civil de la pro-

${ }^{24}$ Children's Act 38 of 2005. http://www.justice.gov.za/legislation/acts/2005-038\%20 childrensact.pdf. Última consulta: 19/02/2013.

${ }^{25}$ Assisted Human Reproduction Act (AHR Act), Assented to 2004-03-29. http:// laws-lois.justice.gc.ca/eng/acts/A-13.4/page-1.html\#docCont. Última consulta: 20/03/2013. 
vincia de Quebec prohíbe cualquier contrato de subrogación, incluidos los altruistas.

Entre los países en que se encuentra prohibida legalmente la gestación por sustitución, además de España, encontramos a Francia, en cuyo artículo 16-7 del Código Civil ${ }^{26}$ se prohíbe cualquier acuerdo que implique la gestación por cuenta de otro, sancionándose expresamente en su Código Penal. O Suiza, cuya Ley federal sobre reproducción médicamente asistida de $1998^{27}$ prohíbe expresamente la maternidad subrogada, estableciendo sanciones. No obstante, si igualmente se lleva a cabo, no se sancionará a la madre subrogada, que será la madre legal del niño nacido.

\section{LA REGULACIÓN ESPAÑOLA.}

En España, están prohibidos los contratos de gestación por sustitución.

La primera ley en España reguladora de las técnicas de reproducción asistida humana, fue la de 22 de noviembre de $1988^{28}$, tan sólo precedida en Europa por la Ley sueca de 1985 sobre inseminación artificial en la pareja ${ }^{29}$.

El avance científico en estas técnicas, supuso la promulgación de la actual Ley 14/2006, de 26 de mayo, sobre Técnicas de Reproducción Humana Asistida, que responde al principio común en los países de la Europa continental de que no sea objeto de tráfico jurídico la gestación y reproducción ${ }^{30}$.

El artículo 10 de la referida Ley 14/2006, sanciona con la nulidad de pleno derecho los contratos que se celebren a dicho respecto, dis-

${ }^{26}$ Code Civil. Version consolidée au 1 janvier 2013. http://www.legifrance.gouv.fr/ affichCode.do?cid Texte=LEGITEXT000006070721\&dateTexte=20130319. Última consulta: 19/02/2013.

${ }^{27}$ Federal Act on Medically Assisted Reproduction (Reproductive Medicine Act, RMA), of 18 December 1998. http://www.admin.ch/ch/e/rs/8/810.11.en.pdf. Última consulta: 19/02/2013.

${ }^{28}$ Ley 35/1988, de 22 de noviembre, sobre técnicas de reproducción asistida. BOE núm. 282, de 24 de noviembre de 1988, páginas 33373 a 33378. Derogada por la actual Ley 14/2006.

${ }^{29}$ RAgel SÁnchez, L. F.: «La determinación de la filiación». Base de datos jurídica on line IUSTEL, pág. 1.

${ }^{30}$ FernándeZ-Sancho Tahoces, A. S.: «Eficacia jurídico-registral del contrato de gestación subrogada», Revista Aranzadi Doctrinal, n. ${ }^{\circ}$ 6/2011, Pamplona, 2011, pág. 22; y BaUtista ZARRALUQUI, J. B.: «Maternidad subrogada», Revista Actualidad Jurídica Aranzadi, n. 815 (Tribuna), Pamplona, 2011, pág. 1. 
poniendo su segundo apartado que «La filiación de los hijos nacidos por gestación de sustitución será determinada por el parto», por lo que la gestante será quien se convertirá en la madre legal del bebé a todos los efectos ${ }^{31}$.

En los artículos 24 y siguientes de la Ley se establece que las infracciones en materia de reproducción humana asistida serán objeto de sanciones de tipo administrativo, sin perjuicio de las responsabilidades civiles, penales o de otro orden que puedan concurrir.

El Código Penal, en su reforma introducida en el año 2003, establece en los artículos 220 a 222 las sanciones jurídico-penales relativas a la suposición del parto y a la alteración de la paternidad, estado o condición del menor ${ }^{32}$.

La prohibición expresa y sanciones que resultan de las citadas normas, conviven en total contradicción con la Ley sobre el Registro Civil de 8 de junio de $1957^{33}$ y con el Reglamento del Registro Civil de 14 de noviembre de $1958^{34}$, que permiten la inscripción de las resoluciones judiciales extranjeras firmes que establecen la filiación del menor como hijo de los padres subrogados, por lo que, en la práctica, nos encontramos con que los contratos de subrogación finalmente alcanzan los efectos jurídicos que no están permitidos en España.

Este hecho ha suscitado una gran polémica, tanto a la hora de ser aplicado en los Registros civiles consulares, como en su interpretación en recientes resoluciones de la Dirección General de los Registros y del Notariado ${ }^{35}$, que han venido admitiendo la inscripción de la

${ }^{31}$ Contiene dicho artículo, par tanto, tal y como establece MARTínEZ-CALCERRADA, L. en "La nueva inseminación artificial (Estudio Ley 22 de noviembre 1988)», Luis Martínez Calcerrada, Torrejón de Ardoz (Madrid), 1988, pág. 303, una prohibición general de la gestación por sustitución y un status de maternidad prevalente.

${ }^{32}$ En el caso de que en España se produjera algún caso de maternidad subrogada, se realizaría de modo delictivo bajo la suposición de parto que sanciona el Código Penal, haciendo pasar por fruto de la pareja estéril el niño dado a luz por la madre gestante, tal y como aseguran Martínez-Pereda Rodríguez, J. M. y MASSIgoge BeneGIU, J. M.. en «La maternidad portadora, subrogada o de encargo en el Derecho español». Dykinson. Madrid, 1994. Págs. 79 y 80.

${ }^{33}$ Dicha Ley de 1957 será derogada con la entrada en vigor el día el 22 de julio de 2014, de la Ley 20/2011, de 21 de julio, del Registro Civil, publicada en el BOE núm. 175 , de 22 de julio de 2011, páginas 81468 a 81502 , la cual se halla en la actualidad en período de "vacatio legis».

${ }^{34}$ Publicado en el BOE de 11 de diciembre de 1958 y actualizado en el BOE de 19 de septiembre de 1986.

${ }^{35}$ Véase, entre otras, la Resolución (1. ${ }^{\text {a }}$ de 18 de febrero de 2009, sobre inscripción de nacimiento acaecido en el extranjero, publicada en Boletín del Ministerio de Justicia, «Resoluciones de la Dirección General de los Registros y del Notariado (Registro Civil). De 7 de enero de 2009 a 28 de febrero de 2009», Ministerio de Justicia, 
filiación de los niños nacidos en el extranjero por subrogación, siempre y cuando exista una resolución judicial dictada por el órgano jurisdiccional competente en la que se determine la filiación del nacido, se haga constar que no se vulnerado el interés superior del menor y recoja el libre consentimiento y renuncia expresa de la gestante, todo ello de acuerdo con lo establecido en la Instrucción de 5 de octubre de 2010 de dicha Dirección General ${ }^{36}$.

El artículo 12.4 del Código civil establece que «se considerará como fraude de Ley la utilización de una norma de conflicto con el fin de eludir una Ley imperativa española», y su apartado 3 que "en ningún caso tendrá aplicación la Ley extranjera cuando resulte contraria al orden público».

Parte de la doctrina ${ }^{37}$, se halla expresamente a favor de la paternidad subrogada, defendiendo expresamente los convenios de gestación por sustitución, con el fin de «solventar problemas de infertilidad que no pueden salvarse mediante los diferentes mecanismos establecidos en las sucesivas leyes de técnicas de reproducción humana asistida» ${ }^{38}$. Pero otros juristas ${ }^{39}$, en cambio, consideran que los que acuden a países extranjeros para tener hijos a partir de la técnica de la gestación

Madrid, 2010, páginas 372 a 379; la Resolución de 30 de noviembre de 2011 (2. ${ }^{\text {, }}$ publicada en Boletín del Ministerio de Justicia, «Resoluciones de la Dirección General de los Registros y del Notariado (Registro Civil). De 1 de noviembre de 2011 a 31 de noviembre de 2011», Ministerio de Justicia, Madrid, 2012, páginas 9 a 12; o la Resolución de 22 de diciembre de 2011 (4. ${ }^{\mathrm{a}}$, publicada en Boletín del Ministerio de Justicia, «Resoluciones de la Dirección General de los Registros y del Notariado (Registro Civil). De 1 de diciembre de 2011 a 30 de diciembre de 2011 ", Ministerio de Justicia, Madrid, 2012, páginas 9 a 12.

${ }^{36}$ Instrucción de 5 de octubre de 2010, de la Dirección General de los Registros y del Notariado, sobre régimen registral de la filiación de los nacidos mediante gestación por sustitución, publicada en el BOE núm. 243, de 7 de octubre de 2010, páginas 84803 a 84805 , que admite la inscripción en el Registro civil de nacimientos producidos en el extranjero como consecuencia de un contrato de gestación por sustitución, siempre que al menos uno de sus solicitantes sea español.

${ }^{37}$ Vela SÁnchez, A. J.: «Propuestas de regulación del Convenio de Gestación por sustitución o de la maternidad subrogada en España». Diario La Ley, n. ${ }^{\circ} 7621$ (Sección Doctrina). Editorial La Ley. Madrid, 2011.

${ }^{38}$ Vela SÁnchez, A. J.: "La gestación por encargo desde el análisis económico del derecho. Medidas anticrisis desde el Derecho de Familia». Diario La Ley, n. ${ }^{\circ} 8055$ (Sección Doctrina). Editorial La Ley. Madrid, 2013.

${ }^{39}$ QuiÑones EscámeZ, A.: «Doble filiación paterna de gemelos nacidos en el extranjeros mediante maternidad subrogada», In Dret, Revista para el análisis del Derecho, julio 2009, pág. 29; o el presidente del Foro Español de la Familia, Don Benigno Blanco, en declaraciones efectuadas al diario ABC el 8 de octubre de 2010, http:// www.abc.es/20101008/sociedad/inscribir-hijos-madresalquiler-20101008. html?loomia_ow=t0: s0: a16: g2: r1: c 0.035553: b38075394: z0. Última consulta: 02/02/2013. 
por sustitución, están cometiendo fraude de Ley, ya que buscan una norma de cobertura para lograr un resultado expresamente prohibido por una norma española, así como que la Ley de Reproducción Asistida vigente constituye una norma de orden público, y por tanto, con efectos de obligado cumplimiento y superioridad en su aplicación y, en especial, la prohibición que afecta a la gestación por sustitución, ya que dicha figura, tal y como menciona la sentencia n. ${ }^{\circ} 826$, de 23 de noviembre de $2011^{40}$, de la sección 10. ${ }^{a}$ de la Audiencia Provincial de Valencia, afecta a principios tales «como el que la persona humana no puede ser objeto del comercio de los hombres, o lo que es lo mismo, que el niño no puede ser objeto de transacción, así la propia dignidad de la persona. Principios reflejados, además de en el artículo 10.1 de la Constitución, en su artículo 15, que reconoce el derecho a la integridad moral, el artículo 39.2 del la misma norma fundamental, que proclama que los poderes públicos aseguran la protección integral de los hijos y de las madres cualquiera que sea su estado civil, el artículo 1.271 del Código Civil, que prescribe que pueden ser objeto de contrato todas las cosas que no están fuera del comercio de los hombres y el artículo 1.275 del mismo cuerpo legal, que impide la producción de efectos a los contratos con causa ilícita».

Precisamente en el supuesto de los vientres de alquiler, aunque el nacimiento del niño se produzca en el extranjero, es en nuestro país donde se producen los efectos últimos del contrato, consistentes en lograr la inscripción de la filiación a favor de los padres comitentes.

No obstante, también debemos tener en cuenta, que es precisamente la propia Ley española la que permite la inscripción de dicha filiación del recién nacido a través de, entre otros, la legislación del Registro civil, el procedimiento de homologación de sentencias extranjeras previsto en la Ley de Enjuiciamiento Civil de 1881, o de mencionada Instrucción de la Dirección General de los Registros y del Notariado de 5 de octubre de 2010, que mencionaremos más adelante, siendo no menos que incongruente que la producción de los efectos derivados de un hecho expresamente prohibido por una Ley española, sea permitida al amparo de otra norma nacional, convirtiendo dicha permisividad en plenamente ineficaz la sanción de nulidad del contrato establecida en el artículo 10 de la Ley 14/2006.

Por todo ello, debemos resaltar la insuficiencia e incongruencia del actual panorama legislativo español en torno a la gestación por sustitución, tanto si el legislador quiere que dicha figura continúe prohibida, como si se pretende permitir libremente que los ciudada-

${ }^{40}$ Id. Cendoj: 46250370102011100707. 
nos españoles acudan a dicha práctica y lograr el resultado esperado en nuestro país, o incluso que sea posible suscribir contratos de paternidad subrogada con plenos efectos jurídicos en España.

\section{LA INSCRIPCIÓN DEL MENOR EN EL REGISTRO CIVIL ESPAÑOL.}

Es clara la necesidad de prestar una singular protección al niño, tanto antes como después de su nacimiento, debido a su falta de madurez física y psicológica, especialmente en el ámbito legal.

En este sentido, son numerosos los instrumentos internacionales que plasman múltiples derechos inherentes a los niños, y obligan a los estados a adoptar las medidas legislativas, administrativas y de otra índole que sean precisas para que se hagan efectivos en la práctica.

La Declaración de los Derechos del Niño de 1959 o la Declaración Universal de Derechos Humanos de 1948, ambos adoptados por la Asamblea General de las Naciones Unidas, o la Declaración de Ginebra de 1924 sobre los Derechos del Niño, contienen especiales menciones encaminadas a lograr el bienestar del menor. Pero son la Convención sobre los Derechos del Niño de 20 de noviembre de 1989 de las Naciones Unidas ${ }^{41}$, o el Pacto Internacional de Derechos Civiles y Políticos de 1966, los que expresamente establecen, entre otros, el deber de respeto a la identidad del niño, así como su derecho a tener un nombre y a ser inscrito inmediatamente después de su nacimiento. La inscripción del menor se enmarca, por tanto, en el ámbito de los derechos del niño.

Con la práctica de la inscripción en el Registro civil español, además de dar cumplimiento a las referidas normas internacionales, se satisfacen las normas nacionales, como el artículo 39 de la Constitución que prevé «la protección integral de los hijos, iguales estos ante la Ley con independencia de su filiación y de la madre», así como su

${ }^{41}$ Tal y como establece GuILló JimÉNEZ, J., la Convención plasma, entre los derechos civiles y políticos de los niños, que son los que les garantizan el que sean respetados como personas, que puedan participar en la sociedad y tomar parte en asuntos relevantes para ellos, recoge en sus artículos 7 y 8 , su derecho a tener un nombre, una nacionalidad y una identidad desde el momento mismo de su nacimiento, así como su derecho a preservar sus relaciones familiares (cit. en «Los derechos de los niños, responsabilidad de todos». Vicente Giménez, T. y Hernández Pedreño, M. -coord.-. Universidad de Murcia. Murcia, 2007. Pág. 89). 
derecho a investigar la paternidad ${ }^{42}$ y a gozar de la protección prevista en los acuerdos internacionales que velan por sus derechos, o las disposiciones de la Ley Orgánica 1/1996, de 15 de enero, de Protección Jurídica del Menor ${ }^{43}$, en cuyo artículo 2 reconoce la primacía del interés superior del menor sobre cualquier otro interés legítimo que pudiera concurrir.

La fe pública registral que deja constancia del hecho del alumbramiento, sienta una presunción "iuris tantum» de exactitud y legalidad de los hechos inscritos, permitiéndose a los que figuran en la inscripción como padres, mostrar a su hijo como tal a todos los efectos lega$\mathrm{les}^{44}$. Con ello, aunque la legislación del Registro civil permita la inscripción a los solos efectos de constancia, supone en la práctica mucho más que eso, ya que comporta el reconocimiento de la filiación.

Al no estar permitida en nuestro país la práctica que nos ocupa, los nacimientos de los bebés siempre se producirán en el extranjero y se inscribirán en primera instancia en el registro del país de que se trate, como las Oficinas de registros vitales estadounidenses, por ejemplo. A continuación, los padres comitentes deberán seguir un procedimiento judicial en dicho país en el que se les atribuya la paternidad del menor, verificando que se haya respetado el interés superior del niño y los derechos de la madre gestante, valorando especialmente si ésta ha renunciado «de manera informada y voluntaria a cualquier derecho que le pudiera corresponder» ${ }^{45}$.

El hecho de que en la propia resolución se declare que los padres intencionales ostentarán los derechos legales sobre el niño y que éste gozará de todos los beneficios que legalmente le correspondan como hijo de aquéllos, aseguran que el menor recibirá la protección y el cuidado necesarios para su bienestar conforme a las exigencias del

${ }^{42}$ No obstante, es cierto, tal y como asegura MaGALDI, N., que la determinación de la filiación, especialmente la materna, se ha complicado hasta límites insospechados a raíz de las nuevas técnicas de reproducción asistida, experimentación con embriones, fecundaciones «in vitro» o "post mortem» y otras prácticas científico-técnicas en la materia (cit. en «Derecho a saber, filiación biológica y Administración Pública». Marcial Pons. Barcelona, 2004. Pág. 17).

${ }^{43}$ Ley Orgánica 1/1996, de 15 de enero, de Protección Jurídica del Menor, de modificación parcial del Código Civil y de la Ley de Enjuiciamiento Civil, publicada en el BOE núm. 15, de 17 de enero de 1996, páginas 1225 a 1238. Dicha Ley es aplicable a los menores de dieciocho años que se encuentren en territorio español.

${ }^{44}$ Hualde Manso, T: «De nuevo sobre la filiación de los nacidos mediante gestación contratada», Aranzadi Civil- mercantil n. ${ }^{\circ}$ 10/2012, Editorial Aranzadi, S. A., Pamplona, 2012.

${ }^{45}$ Resolución 6/2011 de 6 de mayo, de la Dirección General de Registro y Notariado, que establece los requisitos, continuando la línea fijada por la Instrucción de 5 de octubre de 2010. 
artículo 3 de la Convención de 1989 sobre los Derechos del Niño, garantizando su derecho a disponer de una filiación única, válida para todos los países, gozando de una única identidad, principio que ha sido proclamado por diversas sentencias del Tribunal de Justicia de la UE, como la de 2 de octubre de $2003^{46}$ o la de 14 de octubre de $2008^{47}$.

La Ley de 8 de junio de 1957, sobre el Registro Civil, es la actualmente vigente en nuestro país en la materia. No obstante, ya ha sido aprobada la nueva Ley 20/2011, de 21 de julio, del Registro Civil, que se encuentra en periodo de «vacatio legis» hasta el momento de su futura entrada en vigor, por lo que se hace necesario contemplar los procedimientos de ambos cuerpos legales que permiten lograr la inscripción de la filiación del menor nacido mediante técnicas de paternidad subrogada.

\section{PROCEDIMIENTOS DE INSCRIPCIÓN EN BASE A LA VIGENTE LEY SOBRE EL REGISTRO CIVIL DE 1957.}

Conforme a la Ley de 8 de junio de 1957, sobre el Registro Civil, para lograr los padres comitentes la inscripción de la filiación a su favor en el Registro civil español, deberán aportar la sentencia en la que se declare la filiación a su favor, debidamente legalizada o apostillada, en su caso.

Dependiendo de que dicha sentencia haya resultado de un procedimiento análogo a uno español de jurisdicción voluntaria, o que el procedimiento haya tenido carácter contencioso, se podrá lograr la inscripción directamente en el Registro civil consular español radicado en el país extranjero, o se tendrá que acudir al Registro Civil Central radicado en Madrid, tal y como veremos a continuación.

\section{a) Inscripción de sentencias derivadas de procedimientos de jurisdicción voluntaria. La instrucción de la Dirección General de los Registros y del Notariado de 5 de octubre de 2010.}

Debido a los diversos recursos presentados por ciudadanos españoles ante la negativa de los Registros civiles consulares a practicar las inscripciones del nacimiento de niños nacidos en el extranjero a

\footnotetext{
${ }^{46}$ Asunto C-148/02. http://eur-lex.europa.eu/LexUriServ/LexUriServ. do?uri=CELEX: 62002J0148: ES: NOT. Última consulta: 01/02/2013.

${ }_{47}$ Asunto C-353/06, http://eur-lex.europa.eu/LexUriServ/LexUriServ. do?uri=CELEX: 62006J0353: ES: NOT. Última consulta: 01/02/2013.
} 
través de la gestación por sustitución, la Dirección General de los Registros y del Notariado dictó la Instrucción de 5 de octubre de $2010^{48}$, publicada en el BOE núm. 243 de dicho año, a efectos de unificar la práctica registral y con «finalidad de dotar de plena protección jurídica el interés superior del menor, así como de otros intereses presentes en los supuestos de gestación por sustitución», ofreciendo una solución jurídica que muchos entienden quiebra el principio de legalidad del sistema registral español y que merma la seguridad jurídica ${ }^{49}$.

Esta Instrucción resulta de vital importancia en dos ámbitos: el del reconocimiento de la paternidad y el del régimen registral de los nacidos mediante gestación por sustitución, mereciendo ambos, consideraciones críticas.

Así, establece que la inscripción del nacimiento deberá realizarse acompañando a la solicitud de inscripción, la resolución judicial dictada por el Tribunal extranjero competente que determine la filiación. No se admitirá bajo ningún concepto, a efectos de inscripción del nacimiento y filiación, la presentación de certificación registral extranjera o una simple declaración a la que se acompañe una certificación médica del nacimiento en que no conste la identidad de la madre subrogada.

Para el caso de que la resolución judicial extranjera tuviera su origen en un procedimiento análogo a uno español de jurisdicción voluntaria, y remitiéndose a la doctrina del Tribunal Supremo, dispone la instrucción que la inscripción del nacimiento en base a la sentencia no quedará sometida al requisito de homologación, bastando que el encargado del Registro Civil efectúe un control incidental, comprobando la concurrencia de los siguientes extremos: «a) La regularidad y autenticidad formal de la resolución judicial extranjera y de cualesquiera otros documentos que se hubieran presentado. b) Que el Tribunal de origen hubiera basado su competencia judicial internacional en criterios equivalentes a los contemplados en la legislación española. c) Que se hubiesen garantizado los derechos procesales de las partes, en particular, de la madre gestante. d) Que no se ha producido una vulneración del interés superior del menor y de los derechos de la madre gestante. En especial, deberá verificar que el consentimiento de esta última se ha obtenido de forma libre y voluntaria, sin incurrir

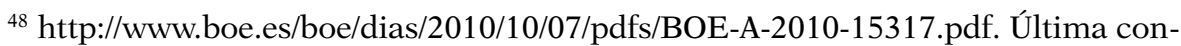
sulta: $14 / 12 / 2013$.

${ }^{49}$ Cerdá SubiRachs, J.: «La insostenible legalización de facto de la maternidad subrogada en España. A propósito de la Instrucción de 5 de octubre de 2010 de la DGRN», Abogados de Familia, n. ${ }^{\circ} 60$ (Sección Tribuna Abierta), Madrid, 2011, pág. 4 y ss. 
en error, dolo o violencia y que tiene capacidad natural suficiente. e) Que la resolución judicial es firme y que los consentimientos prestados son irrevocables, o bien, si estuvieran sujetos a un plazo de revocabilidad conforme a la legislación extranjera aplicable, que éste hubiera transcurrido, sin que quien tenga reconocida facultad de revocación, la hubiera ejercitado.».

La Instrucción parte de la premisa de que con la inscripción del nacimiento en el Registro Civil no se determina la filiación, sino que tan sólo se traslada al Registro civil español una filiación determinada en virtud de una resolución judicial extranjera que ha sido objeto del correspondiente control incidental previo a la inscripción. El objetivo principal de la Instrucción radica en controlar el cumplimiento de los requisitos de perfección y contenido del contrato respecto del marco legal del país donde se ha formalizado, así como la protección de los intereses del menor, verificando que no se trate de un supuesto de simulación que encubra el tráfico internacional de menores, y también el interés de la madre gestante, tratando de comprobar que ostentaba plena capacidad jurídica y de obrar, la eficacia legal del consentimiento prestado por no haber incurrido en error sobre las consecuencias y alcance del mismo, que no fue sometida a engaño, violencia o coacción, e incluso una eventual previsión y/o posterior respeto a la facultad de revocación del consentimiento o cualesquiera otros requisitos previstos en la normativa legal del país de origen.

En defensa de su argumento, la Instrucción entra en valoraciones sobre el refuerzo que la inscripción supone en relación a cualquier acto de tráfico internacional de menores, así como la necesidad de asegurarse de que no se esté vulnerando el derecho del nacido a conocer su origen biológico, de conformidad con lo dispuesto en el artículo 7.1 de la Convención sobre los Derechos del Niño de 1989, el artículo 12 de la Ley 54/2007 de Adopción Internacional, o en la sentencia del Tribunal Supremo de 21 de septiembre de 1999, pero llama la atención el hecho de que la referida Instrucción, no recoja la exigencia del control que debería efectuar el encargado del Registro civil consular de que la filiación que se pretende inscribir es conforme con la legislación española.

Buena parte de la doctrina, entre otros, Doña Susana Salvador Gutiérrez, Magistrada encargada del Registro civil único de Madrid, consideran que la Instrucción comentada se halla afectada de nulidad de pleno derecho por contravenir el artículo 10.1 de la Ley de Repro- 
ducción Asistida ${ }^{50}$. Pese a ello, esta Instrucción ha sentado doctrina y su línea ha sido continuada por posteriores ${ }^{51}$ resoluciones de la Dirección General de los Registros y del Notariado, que han resuelto recursos presentados contra la calificación jurídica inicial del cónsul de España en el país donde se ha realizado la subrogación, al denegar la inscripción en el Registro civil consular de filiaciones derivadas de la misma.

\section{b) Inscripción de sentencias derivadas de procedimientos jurisdiccionales contenciosos. La homologación de las resoluciones extranjeras en España.}

En caso de que el Encargado de la oficina consular estime que la resolución judicial extranjera tiene su origen en un procedimiento jurisdiccional contencioso, denegará la inscripción por considerar la necesidad de acudir al exequátur conforme a la Ley de Enjuiciamiento Civil de 1881, en cuyo caso, los solicitantes podrán acudir a los medios ordinarios de inscripción previstos en el artículo 9.4 del Código civil, que establece que «el carácter y contenido de la filiación, incluida la adoptiva, y las relaciones paterno-filiales, se regirán por la Ley personal del hijo», el artículo 10.3 de la Ley 14/2006, que deja a salvo una posible acción de reclamación de la paternidad respecto del padre biológico, conforme a las reglas generales, o los artículos 764 y siguientes de la Ley de Enjuiciamiento Civil, que establecen los procesos sobre filiación, paternidad y maternidad, en base a los cuales "podrá pedirse de los tribunales la determinación legal de la filiación, así como impugnarse ante ellos la filiación legalmente determinada, en los casos previstos en la legislación civil».

El procedimiento de homologación de sentencias firmes extranjeras, también conocido como «exequátur», se regula en los artículos 951 y siguientes LEC de 1881, que siguen en vigor tras la promulgación de la nueva Ley 1/2000, de 7 de enero, de Enjuiciamiento Civil. En dichos artículos se prevé que dichas sentencias tendrán en nuestro país la fuerza que establezcan los Tratados respectivos, o a falta de éstos, la misma fuerza que en dicho país se le otorgue a las nuestras

${ }^{50}$ SALVAdOR GutiÉRREZ, S.: «Reconocimiento registral de la determinación en el extranjero de doble filiación paterna mediante técnicas de gestación por sustitución», Boletín «Derecho de Familia», n. ${ }^{\circ}$ 126, Madrid, 2012, págs. 4 a 6.

${ }^{51}$ Entre otras, de 3 de mayo de 2011 (EDD 2011/358204), de 6 de mayo de 2011 (EDD 2011/358667), tres de 9 de junio de 2011 (EDD 2011/358209, EDD 2011/358668, EDD 2011/358669), de 27 de junio 2011 (EDD 2011/358668), de 23 de septiembre 2011 (EDD 2011/360049) o de 23 de septiembre de 2011 (EDD 2011/360050). 
sentencias, $\mathrm{o}$, si la ejecutoria procede de un estado en que «por jurisprudencia no se dé cumplimiento a las dictadas por los Tribunales españoles, no tendrá fuerza en España».

Conforme al artículo 954, si no estamos ante ninguno de dichos supuestos, las sentencias tendrán fuerza en España si cumplen con: a) que se haya dictado como consecuencia del ejercicio de una acción personal; b) que no se haya dictado en rebeldía; c) que se haya procedido para el cumplimiento de una obligación lícita en España,; y d)que la sentencia cumpla los requisitos para ser considerada auténtica en el país en que se haya dictado, y los previstos en las leyes españolas.

Una vez homologado el título judicial extranjero, la inscripción registral se practicará aportando, junto a la solicitud de inscripción, el auto judicial que ponga fin al exequátur.

Como el propio Tribunal Supremo ha manifestado en sentencias como las de 21 de octubre de 1997, o de 29 de septiembre y 1 de diciembre de $1998^{52}$, si la resolución extranjera proviene de un procedimiento de jurisdicción voluntaria -como sucede, por ejemplo, en la adopción internacional-, la inscripción de la filiación no estará sometida a exequátur, sino al reconocimiento incidental de la resolución por parte del propio encargado del Registro Civil consular, quien deberá constatar la autenticidad de la resolución, su firmeza, los criterios en que el Tribunal de origen hubiera basado su competencia internacional y que estos sean acordes a la legislación española, la garantía de los derechos procesales de las partes, en especial, de la gestante y del menor, verificando que el consentimiento otorgado por aquélla no haya sido prestado mediando dolo, error o violencia ${ }^{53}$.

Un reciente auto dictado por el Juzgado de primera instancia número 1 de Pozuelo de Alarcón ${ }^{54}$, acuerda el exequátur de una sentencia del Tribunal Superior de Justicia de California que establecía la filiación de dos gemelos nacidos en 2009 a favor de una mujer española. Cuando la madre comitente acudió al Registro Civil Central con la sentencia californiana en la que se la declaraba madre de los niños, le exigieron determinados documentos para practicar la inscripción, como fotos de su embarazo o el nombre del médico que la atendió en el parto, por lo que, no siéndole posible aportarlos, y tras recurrir la decisión, acudió al Juzgado correspondiente para lograr la homologa-

52 EDJ 1997/21532, EDJ 1998/41029 y EDJ 1998/41039.

${ }^{53}$ VELA SÁNCHEZ, A. J.: «La gestación por sustitución o maternidad subrogada: el derecho a recurrir a las madres de alquiler». Diario La Ley, n. ${ }^{\circ} 7608,2011$, pág. 4 y ss.

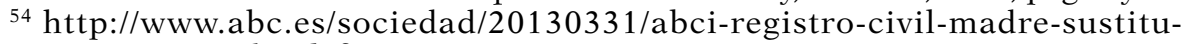
cion-201303311715.html\#formcomentarios 
ción de la sentencia extranjera que reconocía la filiación a su favor. El auto, tras recordar que la legislación española prohíbe la gestación por sustitución, y que filiación, de conformidad con las leyes civiles se determina por el parto, apunta a la existencia de una vía legal que permite inscripción del menor en los casos de reclamación de la paternidad, y dado que en éste caso se daba la ausencia de paternidad, acordó el exequátur, reconociendo la filiación a favor de la madre «en ausencia de paternidad».

\section{c) La inscripción de la filiación a favor de dos personas del mismo sexo.}

La disposición adicional primera de la Ley 3/2007, de 15 de marzo, reguladora de la rectificación registral de la mención relativa al sexo de las personas, que introdujo un apartado 3 al artículo 7 de la Ley 14/2006 sobre técnicas de reproducción humana asistida, permite a una mujer casada con otra mujer «manifestar ante el Encargado del Registro Civil del domicilio conyugal, que consiente en que cuando nazca el hijo de su cónyuge, se determine a su favor la filiación respecto del nacido», pero no la inscripción de la filiación por naturaleza a favor de dos hombres.

Ciertos autores ${ }^{55}$, consideran que ello lleva a una situación de desigualdad con respecto a las parejas formadas por dos hombres, ya que no se les permite la inscripción de la filiación directamente a favor de ambos, vulnerando los principios de igualdad y de prohibición de discriminación por razón de sexo propugnados en el artículo 14 de la Constitución española.

En éste sentido, un matrimonio homosexual formado por dos hombres pretendió en el Registro civil del Consulado de España en Los Ángeles (EEUU), la inscripción a favor de ambos de sus gemelos concebidos en California mediante un contrato de gestación por subrogación, lo cual les fue denegado, procediendo tan sólo a inscribir la filiación a favor de uno de ellos y exigiendo al segundo realizar el proceso de adopción de los niños para que su filiación le fuera reconocida ${ }^{56}$. La pareja se negó a ello y formuló un recurso ante la Dirección General de

${ }^{55}$ DÍAZ-AMBRONA BARDAJÍ, M. D.: «Las técnicas de reproducción humana asistida con especial referencia a las uniones de personas del mismo sexo», pág. 1 y ss., Familia, matrimonio y divorcio en los albores del Siglo XXI. UNED-IDADFE-El Derecho, Madrid, 2006; o BERCOVITZ RODRÍGUEZ-CANO, R.: «Hijos made in California», pág. 2, Aranzadi Civil, n. ${ }^{\circ}$ 3, Aranzadi-Westlaw, Pamplona, 2009.

${ }^{56}$ QUIÑNES ESCÁMEZ, A.: «Doble filiación paterna de gemelos nacidos en el extranjero mediante maternidad subrogada», págs.. 32 a 35, In Dret: Revista para el Análisis del Derecho, n. ${ }^{\circ}$ 3, Editorial Universitat Pompeu Fabra, Barcelona, 2009. 
los Registros y del Notariado, que mediante resolución de 18 de febrero de $2009^{57}$ ordenó la inscripción de la filiación a favor de ambos.

La Fiscalía recurrió esta resolución, cuya tramitación correspondió al Juzgado de Primera Instancia n. ${ }^{\circ} 15$ de Valencia ${ }^{58}$ que estimó la demanda y ordenó la cancelación de la inscripción, sentencia que fue recurrida a su vez en apelación ante la Audiencia Provincial de Valencia, cuya sección $10{ }^{a}$ mediante sentencia n. ${ }^{\circ} 826$ de 23 de noviembre de $2011^{59}$, estableció que dicho artículo 7.3 de la Ley 14/2006 no implica infracción del principio de igualdad, "pues las parejas de dos mujeres no necesitan acudir a otra mujer a la que encomendar la gestación: de modo que no puede considerarse discriminatorio el tratar desigualmente lo que es desigual», y en relación a la gestación por sustitución, manifiesta que la prohibición contenida en dicho artículo es aplicable tanto a las parejas de dos mujeres, como de dos hombres, «de modo que la misma no implica una discriminación por razón de sexo, sino que se fundamenta en la modalidad utilizada para la procreación de los menores, que la ley española considera nula», por lo que se dejó sin efecto la inscripción registral del nacimiento ${ }^{60}$.

Establece la sentencia, que la certificación californiana adolecía asimismo de ciertos defectos, ya que los apelantes manifestaban que había sido expedida por orden de una previa decisión judicial, lo cual no constaba en la misma, como tampoco la identidad de la madre gestante.

\section{EL NUEVO PROCEDIMIENTO DE INSCRIPCIÓN DE DOCUMENTOS JUDICIALES PREVISTO EN LA LEY 20/2011 DEL REGISTRO CIVIL.}

La exigencia de muchos juristas ${ }^{61}$ de una necesaria reforma de la Ley del Registro Civil que se adapte a la realidad social, ha llevado a la aprobación de la nueva Ley 20/2011, de 21 de julio, del Registro Civil $^{62}$, que de acuerdo con su Disposición Final Décima, entrará en

${ }^{57}$ RJ 2009/1735.

${ }^{58}$ Mediante sentencia de 13 de diciembre de 2010. EDJ 2010/262011.

${ }^{59}$ EDJ 2011/280304 o Id. Cendoj: 46250370102011100707.

${ }^{60}$ RUBIO TORRANO, E.: «Inscripción como hijos de un matrimonio de varones, nacidos mediante la gestación por sustitución», págs.. 1 y ss., Aranzadi Civil: revista doctrinal, n. ${ }^{\circ} 9$ (Tribuna), Editorial Aranzadi, S. A., Pamplona. 2011.

${ }^{61}$ Como, entre otros, Don Alfonso Luis Calvo Caravaca, catedrático de Derecho internacional privado de la Universidad Carlos III de Madrid. http://elpais.com/diario/2008/11/09/sociedad/1226185202_850215.html. Última consulta: 30/01/2013.

${ }^{62}$ Publicada en el BOE núm. 175, de 22 de julio de 2011. http://www.boe.es/boe/ dias/2011/07/22/pdfs/BOE-A-2011-12628.pdf. Última consulta: 14/12/2013. 
vigor «a los tres años de su publicación en el Boletín Oficial del Estado», es decir, el próximo 22 de julio de $2014^{63}$.

Bajo el Título X de la nueva Ley 20/2011, se han introducido una serie de normas que establecen -y unifican- el nuevo procedimiento para la inscripción de documentos judiciales y extrajudiciales extranjeros, que deberán ser aplicadas con respeto a la normativa comunitaria y a los tratados e instrumentos internacionales suscritos por España.

La importancia de los hechos que acontecen en el extranjero y que pretenden su acceso al Registro civil, como el supuesto de la gestación por sustitución que nos ocupa, así como la creciente complejidad de los actos y hechos afectados, justifica que la inscripción de todos los documentos judiciales y extrajudiciales otorgados en el extranjero, corresponda con carácter exclusivo a la Oficina Central del Registro, que se configura asimismo como la autoridad encargada en materia de cooperación internacional en todas las materias que se hallen sometidas a la Ley.

Su artículo 95 establece que los documentos extranjeros deberán presentarse en el Registro civil debidamente traducidos y legalizados, a no ser que al Encargado le conste el contenido del documento o su autenticidad, en cuyo caso se prescindirá de dichos requisitos. Si el país cuya autoridad ha expedido el documento público extranjero ha suscrito el XII Convenio de La Haya de 1961, bastará con que en el mismo conste la correspondiente apostilla, sin necesidad de legalización.

En relación con las resoluciones judiciales extranjeras, el artículo 96 establece que deben ser firmes, y si resultan de procedimientos de jurisdicción voluntaria deberán ser definitivas.

Se podrá instar la inscripción de dichas resoluciones judiciales, una vez superado el trámite del exequátur previo previsto en la antigua Ley de Enjuiciamiento Civil de 1881, o bien ante el Encargado del Registro civil que procederá a dicha inscripción una vez haya verificado los siguientes extremos:

${ }^{63}$ Excepto sus Disposiciones Adicionales séptima y octava -relativas a la puesta a disposición de los datos de identificación personal de nacionales y extranjeros y a la inscripción de defunción de desaparecidos durante la guerra civil y la dictadura, respectivamente- y sus Disposiciones Finales tercera y sexta -de reforma del artículo 30 del Código civil y de adquisición de la nacionalidad española por los nietos de exiliados durante la guerra civil y la dictadura, respectivamente-, que entraron en vigor el día siguiente al de su publicación en el Boletín Oficial del Estado, es decir, el 23 de julio de 2011. 
a. La regularidad y autenticidad formal de los documentos presentados.

b. Que el Tribunal de origen hubiera basado su competencia judicial internacional en criterios equivalentes a los contemplados en la legislación española.

c. Que todas las partes fueron debidamente notificadas y con tiempo suficiente para preparar el procedimiento.

d. Que la inscripción de la resolución no resulta manifiestamente incompatible con el orden público español.

Respecto de las resoluciones que carezcan de firmeza o de carácter definitivo, o que hayan seguido el proceso de la homologación previsto en la antigua Ley de Enjuiciamiento Civil, se procederá a su anotación registral en los términos previstos en el ordinal $5 .^{\circ}$ del artículo 40.3, es decir, bajo una «modalidad de asiento que en ningún caso tendrá el valor probatorio que proporciona la inscripción. Tendrán un valor meramente informativo, salvo los casos en que la Ley les atribuya valor de presunción».

La resolución del Encargado del Registro Civil deberá ser notificada a todos los interesados y afectados, y contra la misma se podrá interponer recurso ante la Dirección General de los Registros y del Notariado, o bien solicitar exequátur de la resolución judicial en cuestión.

\section{PROBLEMAS QUE EL INCUMPLIMIENTO DEL CONTRATO PUEDE PLANTEAR EN LA PRÁCTICA.}

¿Qué sucedería si la madre subrogada se arrepiente y no quiere entregar al bebé?. ¿Y si decide interrumpir el embarazo o pide más dinero previamente a la entrega?. ¿Qué sucede si los comitentes quieren recibir un hijo y la gestante se queda embarazada de dos o más?. ¿Y si se echan atrás y no quieren recibirlo?. ¿Y si...?

En la jurisprudencia de EEUU nos encontramos con múltiples supuestos relacionados con incumplimientos de contratos de subrogación. El más conocido es el caso de «Baby M», que tuvo lugar en 1986 en New Jersey. En dicho caso, el acaudalado matrimonio Stern contrató a una madre subrogada, que fue quien también aportó el óvulo para la fecundación, para que gestara a su futura hija. Tras producirse el nacimiento de la niña, la gestante se negó a ceder la custodia alegando que no podía desprenderse del bebé, por lo que los pa- 
dres comitentes iniciaron un procedimiento judicial al respecto ${ }^{64}$. El Juez de primera instancia determinó que el contrato era válido y entregó la custodia al matrimonio Stern, pero la madre biológica apeló al Tribunal Supremo del Estado de New Jersey que revocó el fallo de primera instancia y declaró la nulidad del contrato (al constatar que no se había prestado un consentimiento válido por la madre en la firma del contrato). No obstante, en aplicación de la teoría del interés superior del menor, valoró cuál era la opción que mejor protegía los intereses de la niña y respetó la custodia a favor de los comitentes por considerar que le podrían proporcionar una mejor calidad de vida, concediendo derechos de visita a favor de la madre biológica.

Desde el caso de «Baby $M$ », los Tribunales de EEUU han tenido que pronunciarse en muchas ocasiones, variando los criterios en cada uno de los Estados, como en el caso «Johnson vs Calvert» de $1993^{65}$, en que el Tribunal Supremo de California elaboró la teoría de la intención a la hora de adjudicar la custodia de los menores nacidos mediante esta técnica, en base a la cual hay que determinar quién tenía el verdadero propósito de tener un hijo, o si la madre gestante se habría quedado en cinta de no haber mediado la oferta contractual de los comitentes.

Es innegable que las madres gestantes pueden tener repercusiones psicológicas derivadas del proceso. Unos opinan que es muy fácil que la madre gestante establezca un vínculo con el feto que le haga especialmente difícil separarse del mismo, con riesgo de que caiga en una depresión post-natal y en sentimientos de tristeza y culpabilidad, pero otros proponen que las madres subrogadas, al saber que el bebé que están gestando no les pertenece, tienden a distanciarse del mismo.

En el caso "Doe vs Kelly», un Tribunal de Michigan negó el cumplimiento de la prestación pecuniaria reclamada por la madre de alquiler como contraprestación por el alquiler de su vientre, a excepción de los gastos derivados de la gestación.

Por último, también encontramos en EEUU algún caso en que ha habido gestantes que han logrado quedarse con la custodia de los menores que han dado a luz al ganar la batalla judicial iniciada a dicho

${ }^{64}$ Trial New Jersey Supreme Court decision: in the matter of baby «M», 217 N. J. Super. Ch. 313 (N. J. Super. Ch. 1987). http://www.kylewood.com/familylaw/babym. htm. Última consulta: 05/03/2013.

${ }^{65}$ Pérez Vaquero, C.: «Diez claves para conocer los vientres de alquiler». Artículos doctrinales: Generalidades. Noticias jurídicas. Zaragoza, 2010. Última consulta: 05/03/2013. 
respecto ${ }^{66}$, y con un supuesto en el que se negó la patria potestad a unos padres comitentes que querían quedarse tan sólo con uno de los dos mellizos nacidos y se decidió no separarlos.

En la India, en julio de 2008 nació una niña fruto de una gestación por sustitución encargada por un matrimonio japonés ${ }^{67}$. En el transcurso del embarazo, dicho matrimonio decidió divorciarse y no quiso saber nada del bebé cuando nació, por lo que la pequeña quedó literalmente en el «limbo». Los jueces del Supremo de Japón, donde esta práctica se halla prohibida, quedaron tan confundidos que solicitaron a la fiscalía que aclarase quiénes eran los verdaderos padres y cuál la nacionalidad de la menor, que finalmente fue acogida por su abuela japonesa, viéndose la legislación de dicho país desbordada por una modalidad de gestación familiar que no estaba prevista.

También se han casos en que los padres comitentes han renunciado a los niños nacidos por subrogación al haber conseguido un embarazo propio después de iniciado el proceso, o porque han nacido mellizos o trillizos y sólo querían un hijo, o por no estar de acuerdo con el sexo del bebé, o por haber nacido éste con defectos físicos, o simplemente por falta de madurez.

Ante éstos y muchos otros problemas que pueden surgir en la práctica, la parte que pretendiese el cumplimiento acudiría a los Tribunales para exigir lo propio de la contraparte. Si es la madre subrogada o los intermediarios del país en que se hubiese realizado la gestación los que han incumplido cualesquiera de sus obligaciones, los padres comitentes acudirían a los órganos jurisdiccionales del referido país para exigir el cumplimiento del contrato, los cuáles, tras entrar en el asunto, resolverán lo que proceda. Dicho procedimiento no revestiría, en principio, mayores complicaciones al estar permitida legalmente o, al menos no prohibida, dicha práctica en el país.

Pero en el caso de que fueran unos padres comitentes españoles los que incumplieran, por no querer recibir al menor una vez producido el alumbramiento del mismo, por ejemplo, quién pretendiera obligarles al cumplimiento debería acudir a los Tribunales españoles para ello, con los múltiples dilemas que ello supondría a los juzgadores nacionales al tratarse de un convenio sancionado con la nulidad de pleno derecho en nuestro país. En un principio podríamos entender que deberían inadmitir la demanda, pero al hallarse el interés superior del menor en juego, lo más probable es que tuvieran que

\footnotetext{
${ }^{66} \mathrm{http}: / /$ surrogacy.ru/es/history.php. Última consulta: 04/03/2013.

${ }^{67} \mathrm{http}: / /$ www.elmundo.es/suplementos/cronica/2008/684/1227394805.html. Última consulta: 01/03/2013.
} 
entrar en el fondo del asunto, con todos los dilemas que ello les conllevaría al tratarse de una práctica realizada al margen de nuestra legalidad vigente.

En España se legisla cuando la realidad social, científica o de otra índole lo requiere con urgencia, lo cual da lugar a situaciones que, de haber estado reguladas con anticipación, no se habrían producido ${ }^{68}$, tal y como sucede en relación con la materia que estamos analizando.

En el caso de que en el contrato de subrogación celebrado en el extranjero intervengan ciudadanos españoles residentes en España en calidad de comitentes, a pesar de haberse celebrado el contrato fuera de España, los efectos últimos del contrato consistentes en lograr la inscripción de la filiación del menor, se producen en nuestro país, lo cual convierte en plenamente ineficaz la sanción de nulidad establecida en el artículo 10 de la Ley 14/2006, al lograrse que se produzcan los plenos efectos de lo que constituye la causa del contrato, y que es la efectiva inscripción de la filiación del menor.

Muchos son los juristas ${ }^{69}$ que consideran que el contrato de subrogación contraviene el orden público, así como el respeto a la dignidad y valor de la persona humana consagrados en el artículo 10 de la Constitución, de los cuales se deriva el principio de indisponibilidad del cuerpo humano.

Precisamente, ante todas estas dificultades, la Conferencia de Derecho Internacional Privado de la Haya, elaboró un Informe en abril de 2012 sobre los problemas que plantean los contratos de maternidad subrogada de carácter internacional. Es de especial interés su propuesta de adopción de un instrumento internacional que permita el establecimiento de un marco de cooperación entre autoridades (semejante al que establece el Convenio de La Haya de 29 de mayo de 1993 relativo a la protección del niño y a la cooperación en materia de adopción internacional), que favorecería el reconocimiento de las filiaciones válidamente determinadas en un país que admita esta forma de gestación por sustitución, en otro país cuyo ordenamiento prohíba esta práctica.

${ }^{68}$ Salas Carceller, A.: «El registro civil español y la filiación surgida de la gestación por sustitución», Revista Aranzadi Doctrinal, n. ${ }^{\circ} 10$ (Tribuna), Pamplona, 2010, pág. 1 .

${ }^{69}$ En este sentido, tanto Díaz Romero, M. R.: «La gestación por sustitución...», Op. cit., como FERnÁNDEZ-SANCHO TAHOCES, A. S.: «Eficacia jurídico-registral...», Op. cit. 


\section{CONCLUSIONES.}

1. ${ }^{\text {a }}$ La gestación por encargo de terceros existe desde tiempos inmemoriales bajo su modalidad tradicional. No obstante, la subrogación gestacional, tal como se halla configurada actualmente y basada en técnicas de reproducción asistida, como la inseminación artificial o la fecundación «in vitro», es la que, avanzando de la mano de la ciencia, se encuentra en auge hoy en día.

2. ${ }^{\text {a }}$ Cuando una pareja acude a un profesional del derecho para que intervenga en la tramitación de una paternidad por subrogación, desconocen las dificultades tanto biológicas como legales con las que se van a encontrar y que van a afectar negativamente a su decisión, por lo que deberán ser correctamente asesoradas al respecto antes de iniciar el trámite.

3. ${ }^{\text {a }}$ Los convenios de gestación por sustitución se encuentran expresamente prohibidos y sancionados en nuestro país. Sin embargo, encontramos mecanismos legales que permiten la inscripción registral de los nacidos a partir de dicha técnica, alcanzándose jurídicamente, por tanto, los efectos últimos del contrato, lo que supone una total incongruencia que crea un clima de incertidumbre e inseguridad jurídica, siendo clara la necesidad de una regulación en la materia que proteja a todas las personas que intervienen en el proceso, especialmente, el interés superior del menor y el de la madre gestante mediante, entre otros, el control de que su consentimiento se ha prestado libremente.

4. ${ }^{a}$ La obligación impuesta en el artículo 39.2 de la Constitución Española a los poderes públicos, que deben asegurar la protección integral de los hijos, con independencia de su filiación, hace necesario que deban considerar especialmente el interés superior del menor, el cual se halla asimismo proclamado en tratados internacionales, como la Convención sobre los Derechos del Niño, que entró en vigor el 2 de septiembre de 1990, y legislar en el sentido de dotar a los menores de esa especial protección ante situaciones como la que es objeto del presente trabajo.

5. ${ }^{a}$ Ante la incoherencia, insuficiencia y contradicciones existentes en la normativa española, se hace necesaria una urgente reforma de las normas que afectan a la materia, que disipe la inseguridad jurídica a la que se hallan sometidos los que actualmente acuden, o desean acudir, a dicha práctica, ya sea para 
prohibir completamente dicha práctica mediante mecanismos efectivos, o bien para permitirla en supuestos concretos o en sentido amplio.

6. ${ }^{\text {a }}$ La nueva Ley del Registro Civil supone la unificación legal del procedimiento a seguir para lograr la inscripción de la filiación en base a las resoluciones jurisdiccionales extranjeras que atribuyen la paternidad a los padres comitentes. A partir de su entrada en vigor, será necesario acudir en todo caso al Registro Civil Central a realizar dicho trámite, no siendo competentes en lo sucesivo, los respectivos Consulados de España radicados en el extranjero.

7. ${ }^{\mathrm{a}}$ A efectos del exequátur hay que acudir a las normas previstas en la Ley de Enjuiciamiento Civil de 1881, que sigue vigente en cuanto a la homologación de sentencias extranjeras.

8. ${ }^{\text {a }}$ Muchos países están legislando en la materia y/o adecuando la legislación de que disponen, a la realidad social existente. Pero la tendencia no es uniforme, ya que algunos de ellos tienden a flexibilizar las exigencias, como sucede en el caso de Rusia, en que ya les es posible a parejas no casadas o personas individuales el acceso a la paternidad subrogada (y ya no sólo a parejas heterosexuales casadas); y otros, como la India, tienden a una regulación más restrictiva al respecto.

9. ${ }^{a}$ Es de extrañar que en la Unión Europea, cuya preocupación ha sido constante en materia de Derechos humanos, entre otros, los derechos de la mujer y del niño, no haya existido ninguna iniciativa legislativa ni se haya pronunciado sobre esta práctica, al objeto de regular la maternidad subrogada, de forma que se protegieran los derechos del niño y de las partes implicadas en el proceso, permitiéndose con ello una uniformidad en las legislaciones de todos los países miembros.

10. ${ }^{\mathrm{a}}$ Ante un incumplimiento por parte de la gestante o por parte de los comitentes del convenio, podrán surgir infinidad de los problemas, con el grave perjuicio que esta situación supone para el menor, por lo que es necesaria una correcta regulación normativa de esta figura.

$11 .^{\text {a }}$ En caso de que se acepte legalmente la paternidad por subrogación, debería procederse con gran cautela, especificando los supuestos en que se permitiría, y adelantándose a los posibles excesos que se pudieran cometer con tal de evitar supuestos de comercio con la vida humana. 
X. BIBLIOGRAFÍA.

ALES URÍA ACEVEDO, M. M.: El derecho a la identidad en la filiación. Tirant lo Blanch. Valencia, 2012.

BAUTISTA ZARRALUQUI, J. B.: «Maternidad subrogada». Revista Actualidad Jurídica Aranzadi, n. ${ }^{\circ} 815$ (Tribuna). Editorial Aranzadi, S. A. Pamplona, 2011.

BERCOVITZ RODRÍGUEZ-CANO, R.: «Hijos made in California». Aranzadi Civil Revista Doctrinal, n. 3 (Tribuna). Aranzadi-Westlaw. Pamplona, 2009.

BLANCO RODRÍGUEZ, B.: «La ley española de fecundación «in vitro»: un cambio del modelo de familia». Cuadernos de Bioética (vol. 1), n. ${ }^{\circ}$ 1. AEBI. Madrid, 1990.

CARCABA FERNÁNDEZ, M.: Los problemas jurídicos planteados por las nuevas técnicas de procreación humana. J. M. Bosch Editor, S. A.. Barcelona, 1995.

CERDÁ SUBIRACHS, J.: «La insostenible legalización de facto de la maternidad subrogada en España. A propósito de la Instrucción de 5 de octubre de 2010 de la DGRN». Abogados de Familia, n. ${ }^{\circ}$ 60. La Ley. Madrid, 2011.

DÍAZ-AMBRONA BARDAJÍ, M. D.: «Las técnicas de reproducción humana asistida con especial referencia a las uniones de personas del mismo sexo». Familia, matrimonio y divorcio en los albores del Siglo XXI. UNED-IDADFE-El Derecho. Madrid, 2006.

DÍAZ ROMERO, M. R.: «La gestación por sustitución en nuestro ordenamiento jurídico». Diario La Ley, n. ${ }^{\circ}$ 7527. Editorial La Ley. Madrid, 2010.

FERNÁNDEZ-SANCHO TAHOCES, A. S.: «Eficacia jurídico-registral del contrato de gestación subrogada». Aranzadi Doctrinal, n. ${ }^{\circ}$ 6/2011. Editorial Aranzadi, S. A. Pamplona, 2011.

GARCÍA RUIZ, Y.: Reproducción humana asistida. Derecho, conciencia y libertad. Ed. Comares. Albolote (Granada), 2004.

GUGUCHEVA, M.: Surrogacy in America. Council for Responsible Genetics. Cambridge (EEUU), 2010.

HIERRO HIERRO, F. J.: «Gestación por sustitución y prestación de maternidad». Aranzadi Social: Revista doctrinal (v. 5), n. ${ }^{\circ}$ 6. Aranzadi. Pamplona, 2012. 
HUALDE MANSO, M. T.: «De nuevo sobre la filiación de los nacidos mediante gestación contratada». Aranzadi Civil-mercantil. Revista doctrinal (vol. 1), n. ${ }^{\circ}$ 10. Aranzadi. Pamplona, 2012.

MAGALDI, N.: Derecho a saber, filiación biológica y Administración Pública. Marcial Pons. Barcelona, 2004.

MARTÍNEZ-CALCERRADA, L.: La nueva inseminación artificial (Estudio Ley 22 de noviembre 1988). Luis Martínez Calcerrada. Torrejón de Ardoz (Madrid), 1988.

MARTÍNEZ-PEREDA RODRÍGUEZ, J. M. y MASSIGOGE BENEGIU, J. M..: La maternidad portadora, subrogada o de encargo en el Derecho español. Dykinson. Madrid, 1994.

MORÁN DE VICENZI, C.: El concepto de filiación en la fecundación artificial. Universidad de Piura y Ara Editores. Perú, 2005.

PÉREZ VAQUERO, C.: «Diez claves para conocer los vientres de alquiler». Artículos doctrinales: Generalidades. Noticias jurídicas. Zaragoza, 2010.

QUIÑONES ESCÁMEZ, A.: «Doble filiación paterna de gemelos nacidos en el extranjero mediante maternidad subrogada». Indret, n. ${ }^{\circ}$ 3. Editorial Universitat Pompeu Fabra. Barcelona, 2009.

RAGEL SÁNCHEZ, L. F.: La determinación de la filiación. IUSTEL. Madrid, 2010.

RUBIO TORRANO, E.: «Inscripción como hijos de un matrimonio de varones, nacidos mediante la gestación por sustitución». Aranzadi Civil, n. ${ }^{\circ} 9$ (Tribuna). Aranzadi. Pamplona. 2011.

SALAS CARCELLER, A.: «El Registro Civil español y la filiación surgida de la gestación por sustitución». Aranzadi Doctrinal, n. ${ }^{\circ} 10$. Aranzadi, S. A. Pamplona, 2010.

SALVADOR GUTIÉRREZ, S.: «Reconocimiento registral de la determinación en el extranjero de doble filiación paterna mediante técnicas de gestación por sustitución». Boletín «Derecho de Familia», n. ${ }^{\circ}$ 126. El Derecho. Madrid, 2012.

SELMA PENALVA, A.: «Vientres de alquiler y prestación por maternidad». Aranzadi Social: Revista doctrinal (vol. 5), n. ${ }^{\circ}$ 9. Aranzadi, S. A. Pamplona, 2013.

SOTO LAMADRID, M. A.: Biogenética, filiación y delito. Editorial Astrea. Buenos Aires, 1990. 
VAQUERO LÓPEZ, C.: «Maternidad subrogada, orden público y Ley del Registro Civil». Lex Nova blogs. Editorial Lex Nova, S. A. U. Valladolid, 2012.

VELA SÁNCHEZ, A. J.: «La gestación por sustitución o maternidad subrogada: el derecho a recurrir a las madres de alquiler». Diario La Ley, n. ${ }^{\circ}$ 7608. Editorial La Ley. Madrid, 2011.

VELA SÁNCHEZ, A. J.: «Propuestas de regulación del Convenio de Gestación por sustitución o de la maternidad subrogada en España». Diario La Ley, n. ${ }^{\circ}$ 7621. Editorial La Ley. Madrid, 2011.

VELA SÁNCHEZ, A. J.: «La gestación por encargo desde el análisis económico del derecho. Medidas anticrisis desde el Derecho de Familia». Diario La Ley, n. . 8055. La Ley. Madrid, 2013.

VICENTE GIMÉNEZ, T. y HERNÁNDEZ PEDREÑO, M. (coord.): Los derechos de los niños, responsabilidad de todos. Universidad de Murcia. Murcia, 2007. 
